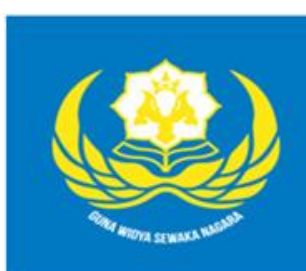

Linguistic Community Services Journal

Vol. 2, No. I, 202 I

P-ISSN: 2406-9019| E-ISSN: 2443-0668

Available online at

https://www.ejournal.warmadewa.ac.id/index.php/licosjournal

DOI: https://doi.org/ I 0.22225/licosjournal.v2i I .3 I 34 30-37

\title{
PELATIHAN BAHASA INGGRIS UNTUK TOUR GUIDE DI KELURAHAN SEMARAPURA KAJA DALAM RANGKA PENGEMBANGAN PARIWISATA TERINTEGRASI
}

\author{
Nyoman Sujaya \\ Universitas Warmadewa, Denpasar-Bali \\ nyomansujaya753@gmail.com
}

\begin{abstract}
Abstrak
Saat ini aktivitas masyarakat Semarapura Kaja mengalami ketidakoptimalan dikarenakan pandemik Covid-19 yang menjadi hambatan untuk bekerja seperti biasanya salah satunya yatitu masyarakat di Kabupaten Klungkung. Permasalahan yang dihadapi oleh masyarakat Semarapura Kaja, yaitu kurangnya kemampuan berbahasa inggris di kalangan pemuda desa Semarapura Kaja dibidang pariwisata sebagai tour guide. Kurangnya pelatihan atau sarana pengajaran bahasa Inggris ini baik secara sosialisasi maupun praktik lapangan, maka solusi yang ditawarkan serta tujuan diselenggarakannya kegiatan pengabdian kepada masyarakat adalah melakukan kegiatan program kemitraan pelatihan bahasa Inggris untuk tour guide di Kelurahan Semarapura Kaja guna mempromosikan daerah wisata/jasa yang ditawarkan. Metode yang digunakan dalam penelitian ini yaitu penelitian kualitatif melalui tahap wawancara untuk mengetahui permasalahan mitra. Sumber data yang digunakan dalam penelitian ini adalah data primer dengan melakukan observasi lapangan untuk mengetahui permasalahan yang dihadapi masyarakat setempat Hasil penelitian menunjukkan bahwa adanya peningkatan dalam memahami penggunaan bahasa Inggris untuk tour guide serta mampu mendeskripsikan petunjuk atau tempat wisata dengan bahasa Inggris.
\end{abstract}

Kata Kunci : Inggris; Pariwisata; Pemandu Wisata

\begin{abstract}
Currently, the activities of the Semarapura Kaja community are not optimizing due to the Covid-19 pandemic which is an obstacle to working as usual, one of which is the people in Klungkung Regency. The problem faced by the Semarapura Kaja community, namely the lack of English language skills among the youth of Semarapura Kaja village in the field of tourism as a tour guide. Lack of training or English teaching facilities both in terms of socialization and field practice, the solution offered and the purpose of holding community service activities is to carry out English training partnership program activities for tour guides in Semarapura Kaja Village to promote the tourist areas / services offered. The method used in this research is qualitative research through the interview stage to find out partner problems. Sources of data used in this study are primary data by conducting field observations to determine the problems faced by the local community. The results show that there is an
\end{abstract}


increase in understanding the use of English for tour guides and being able to describe directions or tourist attractions in English

\section{Keywords: English; Tourism; Tour Guide}

\section{PENDAHULUAN}

Bali merupakan salah satu pusat wisata terkenal yang ada Indonesia. Sebagai pusat pariwisata terbesar, Bali tidak hanya terkenal di Indonesia namun juga mancanegara. Pulau ini menyuguhkan berbagai macam tempat wisata yang menawarkan daya tarik dan keunikan masing-masing dengan banyaknya ragam pilihan dengan resor terbaik. Selain terkenal dengan objek wisata alamnya, Bali juga terkenal akan kekayaan budaya yang sampai saat ini masih dilestarikan. Hal ini dapat menjadi salah satu daya tarik bagi wisatawan dan dapat memberikan manfaat bagi masyarakat dan meningkatkan kesejahteraan ditinjau dari sektor perekonomian. Saat ini pariwisata merupakan primadona di seluruh dunia, kegiatan pariwisata merupakan kegiatan yang dapat mendatangkan manfaat dan keuntungan bagi negara-negara yang sebagai penerima kunjungan wisatawan, sehingga membuat sebagian negara didunia begitupun dengan Indonesia, menganggap pariwisata merupakan sebuah aspek penting dari strategi pengembangan negara. Pariwisata adalah serangkaian kegiatan perjalanan yang dilakukan oleh perorangan atau keluarga ataun kelompok dari tempat tinggal asalnya ke berbagai tempat lain dengan tujuan melakukan kunjungan wisata dan bukan untuk bekerja atau mencari penghasilan ditempat tujuan (Soedarso et al., 2014). Saat ini pariwisata merupakan salah satu penyumbang devisa terbesar bagi negara Indonesia. Hingga saat ini banyak wisatawan yang datang berkunjung ke Indonesia untuk menikmati potensi wisata yang tidak dapat ditemukan di negara mereka. Indonesia terkenal dengan budayanya yang kental yang menjadikan salah satu potensi wisata untuk menarik wisatawan datang berkunjung (Febriani \& Suryawan, 2020).

Pariwisata menjadi andalan utama sumber devisa karena Indonesia merupakan salah satu Negara yang memiliki beraneka ragam jenis pariwisata, seperti wisata alam, sosial maupun wisata. Pengembangan objek membutuhkan kerjasama seluruh pemangku kepentingan yang terdiri dari masyarakat dan pemerintah. Sesuai dengan tugas dan kewenangannya, pemerintah merupakan pihak fasilitator yang memiliki peran dan fungsinya dalam pembuatan dan penentu seluruh kebijakan terkait pengembangan objek dan daya tarik wisata. Daya tarik dalam objek wisata merupakan salah satu modal utama yang harus dimiliki dalam upaya peningkatan dan pengembangan objek wisata, hal ini disebabkan karena faktor utama yang membuat pengunjung atau wisatawan untuk mengunjungi daerah tujuan wisata adalah potensi dan daya tarik yang dimiliki obyek wisata tersebut (Salambue et al., 2020).

Menurut Suwena \& Widyatmaja, (2010) kegiatan pariwisata berkembang dibedakan menjadi (1) Pariwisata lokal (local tourism) yaitu jenis kepariwisataan yang ruang lingkupnya lebih sempit dan terbatas dalam tempat-tempat tertentu saja. Misalnya kepariwisataan kota Denpasar, kepariwisataan kota Bandung; (2) Pariwisata regional (regional tourism) yaitu kegiatan kepariwisataan yang dikembangkan dalam suatu wilayah tertentu, dapat regional dalam lingkungan nasional dan dapat pula regional dalam ruang lingkup internasional. Misalnya kepariwisataan Bali, Yogyakarta, dan lain-lain; (3) Pariwisata nasional (national tourism) yaitu jenis pariwisata yang dikembangkan dalam wilayah suatu negara, dimana para pesertanya tidak saja terdiri dari warganegaranya sendiri tetapi juga orang asing yang terdiam di negara tersebut. Misalnya kepariwisataan yang ada di daerah-daerah dalam satu wilayah Indonesia; (4) Pariwisata regional-internasional yaitu kegiatan kepariwisataan yang berkembang di suatu wilayah internasional yang terbatas, tetapi melewati batas-batas lebih dari dua atau tiga negara dalam wilayah tersebut. Misalnya kepariwisataan ASEAN; (5) 
Pariwisata internasional (International tourism) yaitu kegiatan kepariwisataan yang terdapat atau dikembangkan di banyak negara di dunia.

Tidak dapat dipungkiri kemasyhuran akan kekayaan pariwisata Bali mendunia secara global yang secara langsung dikunjungi oleh wisatawan atau turis yang berasal dari luar negeri. Pengaplikasian dan pemanfaatan bahasa Inggris sangat diperlukan sebagai bentuk media komunikasi agar turis mudah memahami wisata yang dijabarkan oleh masyarakat lokal. Menurut Damayanti, (2019) yaitu (1) Communicative/Interactive Role ini merupakan peran paling utama Bahasa Inggris dalam dunia pariwisata. Bahasa Inggris merupakan media komunikasi antara pelaku wisata dengan wisatawan maupun antar wisatawan. Ketika orang dari berbagai negara datang dan mengunjungi suatu tujuan wisata maka bahasa asal tidak dapat lagi dipergunakan karena itu akan sulit dipahami oleh orang lain. Begitu pula para pelaku wisata yang biasanya merupakan orang lokal juga tidak dapat menggunakan bahasa daerahnya karena para wisatawan tidak akan memahaminya. Maka pelaku wisata dan wisatawan perlu menggunakan sebuah bahasa yang kedua belah pihak ketahui. Pada kasus seperti inilah Bahasa Inggris memiliki peranan yang sangat penting, yaitu sebagai medium komunikasi antara kedua belah pihak. (2) Integrative Role, selain memiliki peran sebagai medium komunikasi, Bahasa Inggris merupakan pemersatu. Seperti diketahui kegiatan pariwisata melibatkan banyak orang dari berbagai negara, adat, budaya, ras, dan kepentingan. Bahasa Inggris mengambil peran dalam mengintegrasikan semua orang tanpa mengenal latar belakang orang-orang tersebut. (3) Lingua-Franca Role, peran Bahasa Inggris sebagai Lingua-Franca memiliki kemiripan dengan peran Bahasa Inggris sebagai medium komunikasi antar pihak dalam dunia pariwisata. Satu orang wisatawan tidak hanya bepergian ke satu negara saja, banyak diantara para wisatawan yang berkunjung ke lebih dari 1 negara. Ini merupakan hal yang sulit jika seorang wisatawan harus belajar bahasa yang digunakan di negara tujuan sebelum ia mengunjunginya. Bahasa Inggris merupakan jembatan bagi wisatawan dan pelaku wisata. Lingua-Franca dapat diartikan sebagai bahasa pengantar atau pergaulan bagi orang-orang yang berada di lingkungan dengan beragam bahasa. (4) RelationFostering Role Bahasa Inggris turut membantu manusia untuk membentuk atau memperkuat hubungan antar manusia, khususnya hubungan yang bersifat global. Dalam dunia pariwisata, Bahasa Inggris memungkinkan wisatawan turut serta dalam kegiatan atau aktifitas masyarakat lokal. Ini dikarenakan para wisatawan dapat terlibat dalam dialog dan diskusi dengan masyarakat lainnya dengan menggunakan media Bahasa Inggris. (5) Economic/Business Role, globalisasi memudahkan tenaga kerja dari berbagai negara untuk datang dan bekerja di suatu negara. Bahkan perdagangan lintas negara pun dapat dilakukan dengan mudah saat ini. Peran Bahasa Inggris sangat besar dalam hal bisnis dan ekonomi. Bahasa Inggris menjadi pengantar dalam bisnis, khususnya dalam bisnis pariwisata. (6) Peran terakhir Bahasa Inggris dalam dunia pariwisata adalah functional role. Peran ini membantu wisatawan maupun masyarakat lokal dalam memperoleh informasi tertentu, meminta bantuan, dan fungsi-fungsi lain yang diperlukan dalam kegiatan berwisata.

Dalam hal ini maka upaya meningkatkan kemampuan berbahasa Inggris kepada masyarakat Desa Semarapura Kaja, Kabupaten Klungkung yaitu dengan mengusulkan pengajaran peningkatan pengetahuan generasi muda terkait penggunaan bahasa Inggris guna memperkenalkan wisata-wisata yang ada di desa tersebut. Manfaat yang akan diperoleh dalam penelitian ini adalah (1) Mendukung upaya pemerintah daerah untuk mempromosikan objek wisata yang dimiliki oleh Desa Semarapura Kaja (2) Meningkatkan daya saing kepariwisataan Desa Semarapura Kaja (3) Menarik perhatian wisatawan lokal maupun mancanegara (4) Memberikan dedikasi positif guna meningkatkan sektor perekonomian bagi warga setempat (5) Memberikan jasa berupa informasi yang jelas kepada para wisatawan 
yang berkunjung khususnya turis dengan menggunakan bahasa Inggris (6) Menumbuhkan citra yang positif bagi Desa Semarapura Kaja sebagai daerah tujuan pariwisata.

\section{METODE PENELITIAN}

Penelitian ini dilakukan di Desa Semapura Kaja, Kabupaten Klungkung, Provinsi Bali pada bulan November dengan melakukan survey yang targetnya merupakan masyarakat yang berada di desa tersebut. Selanjutnya, penelitian ini menggunakan metode wawancara mendalam (in depth interview) kepada pihak yang terlibat guna memperoleh data kualitatif. Pendekatan kualitatif dipandang mampu menggali pemaknaan terhadap fenomena secara lebih mendalam (Creswell, 2017). Data dikumpulkan secara bertahap dengan menanyakan kendala-kendala yang dialami saat belajar bahasa Inggris. Pendekatan yang digunakan dalam penelitian ini adalah deskriptif kualitatif yaitu pengamatan atau pengukuran secara cermat terhadap fenomena sosial yang terjadi pada masyarakat. Data dalam penelitian ini adalah data yang diperoleh langsung peneliti dari lapangan melalui pengamatan selama pelatihan itu berlangsung Hasil data yang diperoleh akan diuraikan secara deskriptif.

Terdapat tiga tahapan dalam melaksanakan kegiatan pengabdian masyarakat ini:

a) Program awal adalah program yang direncanakan guna mendapatkan dukungan kepada masyarakat setempat. Pada tahap ini kunjungan berupa sosialisasi, hal ini dilakukan kepada masyarakat untuk menyampaikan maksud dan tujuan kegiatan di desa mereka.

b) Program inti adalah program yang direncanakan dan dalam pelaksanaanya sesuai dengan potensi yang bisa dikembangkan ditempat wisata tersebut, adapun program ini berupa pengajaran bahasa Inggris guna meningkatkan pemahaman dan sebagai persiapan awal untuk mengaplikasikan bahasa Inggris sebagai pembendaharaan kosa kata yang terkait dengan wisata-wisata yang ada di Desa Semarapura Kaja, Kabupaten Klungkung. Pelaksanaan kegiatan ini dilakukan sesuai dengan target yang telah ditetapkan.

c) Program akhir yang merupakan tahap penutupan yang berupa penyusunan laporan kegiatan yang telah dilakukan.

\section{HASIL DAN PEMBAHASAN \\ Potensi Pengembangan Masyarakat}

Program pengabdian kepada masyarakat (PKM) yang diselenggarakan oleh Universitas Warmadewa, Prodi Magister Ilmu Linguistik bertujuan agar meningkatnya daya tarik masyarakat terhadap wisata yang ada di Desa Semarapura Kaja, Kabupaten Klungkung. Beberapa manfaat yang dihasilkan dari program ini yaitu :

1. Adanya pelatihan berbahasa Inggris khusus untuk tour guide, seperti bahasa Inggris yang komunikatif dan atraktif dengan target capaian memberikan pengetahuan guna menarik minat masyarakat/pemuda untuk kegiatan pelatihan bahasa Inggris.

2. Adanya pelatihan berbahasa Inggris yang tepat untuk mendeskripsikan petunjuk dan tempat-tempat wisata di daerahnya dengan target capaian membuat kegiatan secara mandiri dan praktek kepada masyarakat/pemuda setempat.

3. Pelaksanaan seminar dan pelatihan pemuda desa Semarapura Kaja mengenai tour guide dengan target capaian pengajaran peningkatan pengetahuan generasi muda terkait penggunaan bahasa inggris.

4. Pengadaan seminar-seminar mengenai beberapa tempat wisata yang bisa dikembangkan di Kabupaten Klungkung dengan target capaian meningkatkan kesadaran masyarakat tentang pariwisata. 


\section{Solusi Pengembangan Masyarakat}

Terdapat beberapa tahapan yang diselenggarakan guna mendapatkan manfaat dari program pengabdian kepada masyarakat (PKM) ini adalah :

\section{Sosialisasi dengan masyarakat Desa Semarapura Kaja, Kabupaten Klungkung}

Sosialisasi dengan masyarakat mengenai program ini merupakan salah satu bentuk kemitraan atau kerjasama antara pihak Universitas Warmadewa dan masyarakat setempat. Pada tahap sosialisasi membahas tentang program kegiatan yang dirancang oleh pihak Universitas Warmadewa mengenai pemanfaatan bahasa Inggris bagi masyarakat setempat dan hal ini merupakan satu langkah untuk melestarikan obyek wisata dengan memberikan ilmu linguistik, agar masyarakat setempat mudah berkomunikasi ketika turis atau wisatawan asing datang berkunjung ke Desa Semarapura Kaja.
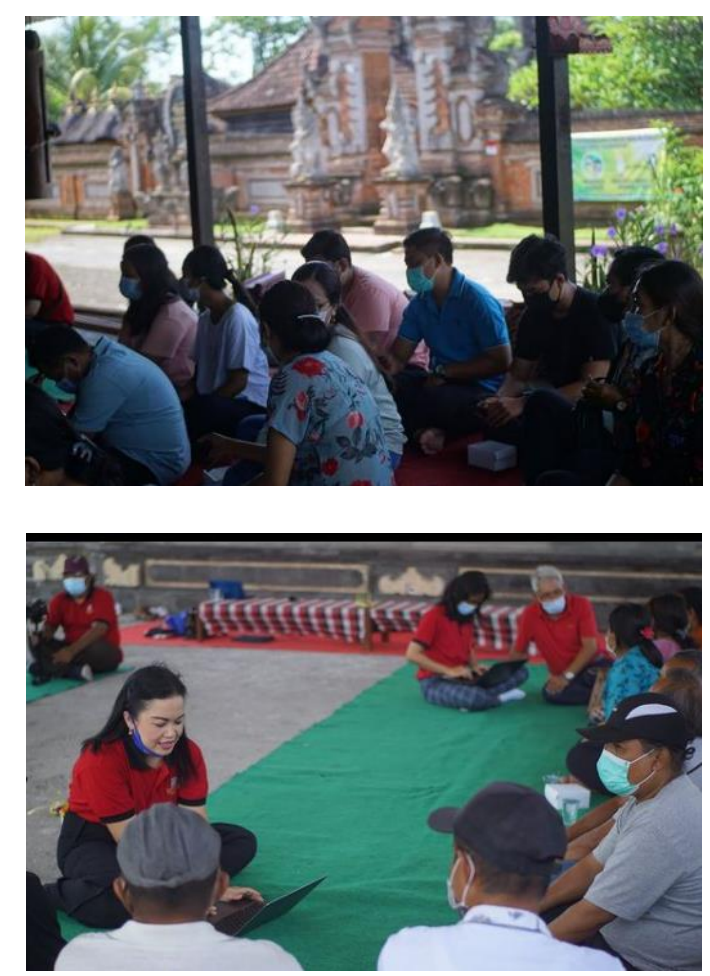

Gambar 1. Sosialisasi pentingnya bahasa Inggris kepada generasi muda

Salah satu target utama dalam kegiatan ini adalah para generasi muda yang hendak melanjutkan pelestarian wisata yang terdapat di desa setempat dalam rangka pengembangan wisata terintegrasi. Peran generasi muda sangat penting untuk menciptakan pariwisata berstandar internasional yang dimana targetnya yaitu turis mancanegara, selain pemertahanan dan pelesarian wisata, namun terdapat harapan besar dikenalinya obyek wisata di Indonesia maupun luar negeri yang juga berpengaruh pada meningkatnya kesejahteraan masyarakat maupun pemerintah daerah setempat dalam sektor ekonomi dan pariwisata. Sebab pengembangan pariwisata sama dengan pengembangan sektor lain juga selalu memiliki dampak bagi perkembangan masyarakat maupun kawasan sekitarnya, baik dampak positif maupun negatif. Karena pertimbangan tersebut, maka diperlukan adanya perencanaan yang matang dalam pengembangan kepariwisataan, agar dampak positif dapat dioptimalkan kemanfaatannya dan dampak negatif dapat diminimalkan atau bahkan dihilangkan (Primadona, 2011). 


\section{Konsolidasi Masyarakat terkait kepariwisataan}

Konsolidasi atau tindakan untuk memperteguh atau memperkuat persatuan guna melestarikan obyek wisata yang ada di Desa Semarapura Kaja merupakan salah satu dasar atau pilar demi meningkatnya kuantitas atau kapasitas wisatawan dan kesejahteraan masyarakat lokal maupun daerah setempat. Hal ini sangat berkaitan erat dengan ekonomi kreatif. Ekonomi kreatif adalah suatu konsep untuk merealisasikan pembangunan ekonomi yang berkelanjutan berbasis kreativitas. Pemanfaatan sumber daya yang bukan hanya terbarukan, bahkan tidak terbatas, yaitu ide, gagasan, bakat atau talenta dan kreativitas. (Purnomo, 2016) Tercatat beberapa hal yang menjadi karakteristik dari ekonomi kreatif, yaitu (1) Diperlukan kolaborasi antara berbagai aktor yang berperan dalam industri kreatif, yaitu cendekiawan (kaum intelektual), dunia usaha, dan pemerintah yang merupakan prasyarat mendasar (2) Berbasis pada ide atau gagasan (3) Pengembangan tidak terbatas dalam berbagai bidang usaha (4) Konsep yang dibangun bersifat relatif (Sumarin et al., 2017).

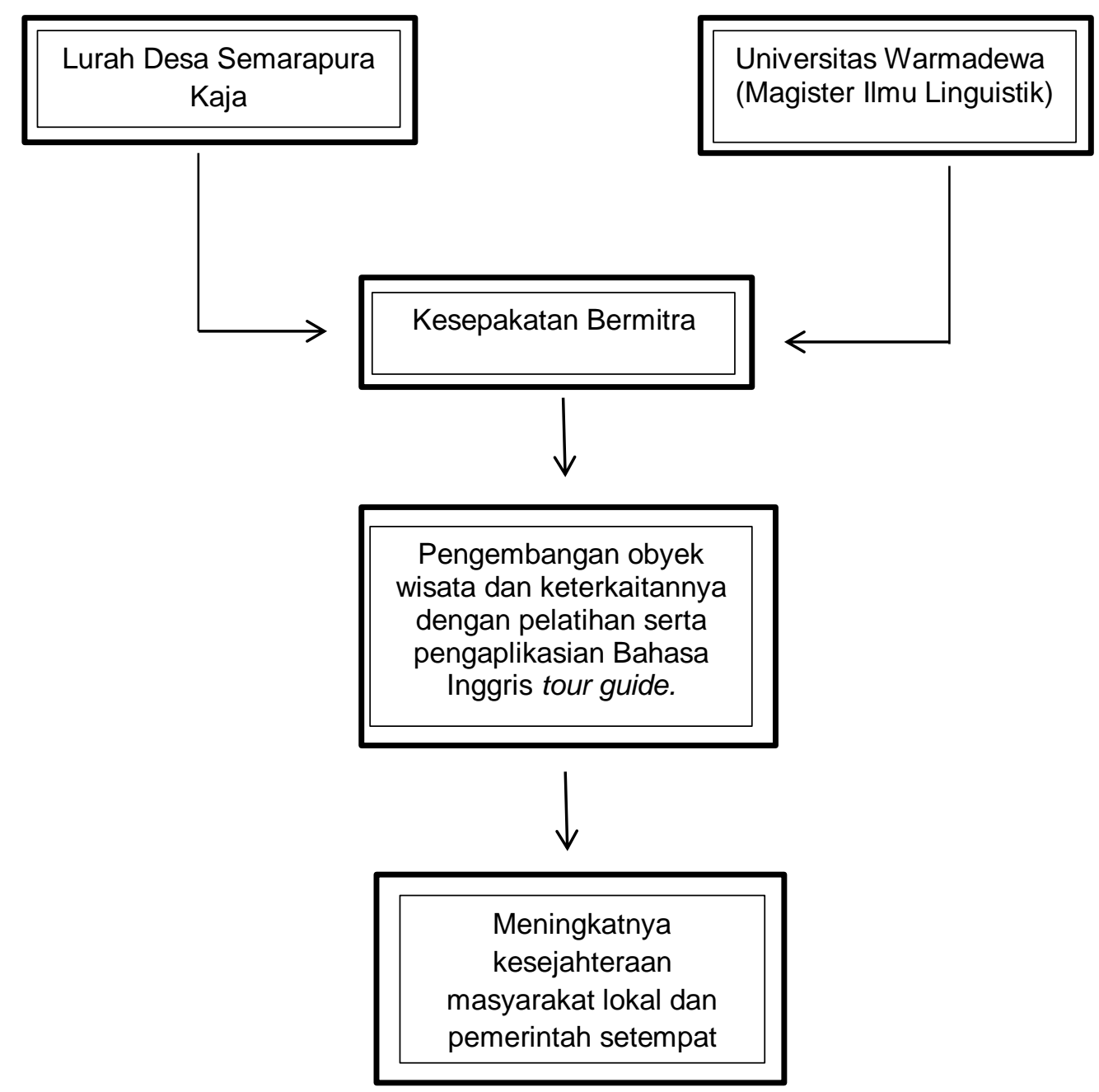

Gambar 2. Alur/bagan proses konsolidasi masyarakat terkait pariwisata terintegrasi 


\section{Pelatihan Bahasa Inggris Tour Guide dalam rangka pengembangan pariwisata terintegrasi}

Bahasa Inggris memiliki peranan penting dalam kehidupan, sebagai bahasa yang bertaraf Internasional, patut dikuasai dan diaplikasikan dalam kehidupan sehari-hari khususnya keterkaitannya dengan kepariwisataan. Bali merupakan salah satu daerah yang menyediakan wisata dengan berbagai destinasi yang kaya akan kebudayaannya. Patut diketahui Bali telah terkenal hingga mancanegara, jadi untuk menarik perhatian wisatawan luar, maka perlu ditingkatkannya pemahaman bahasa Inggris agar dapat diaplikasikan dalam kehidupan sehari-hari. Bahasa Inggris adalah bahasa yang dominan digunakan dan hal ini menjadi suatu keharusan untuk memasuki tenaga kerja global. Menyadari pentingnya bahasa Inggris saat ini, pelajar Indonesia telah mempelajarinya untuk berbagai keperluan, terutama bagi masyarakat untuk mendapatkan ilmu dan mengadopsinya teknologi canggih untuk pembangunan nasional kita. Pengajaran bahasa Inggris itu sendiri dikembangkan, diubah, dan diinovasi. Sebagai respon dari tingginya permintaan bahasa Inggris, bahasa Inggris untuk tujuan tertentu (ESP) yang diklasifikasikan ke dalam bahasa Inggris untuk Academic Purposes (EAP) dan English for Occupied Purposes (EOP) telah muncul. Dalam era globalisasi, bahasa Inggris menjadi lebih penting artinya komunikasi di dunia. Itu dianggap sebagai bahasa Internasional dan bahasa paling favorit di dunia pariwisata (Syukur, 2017)
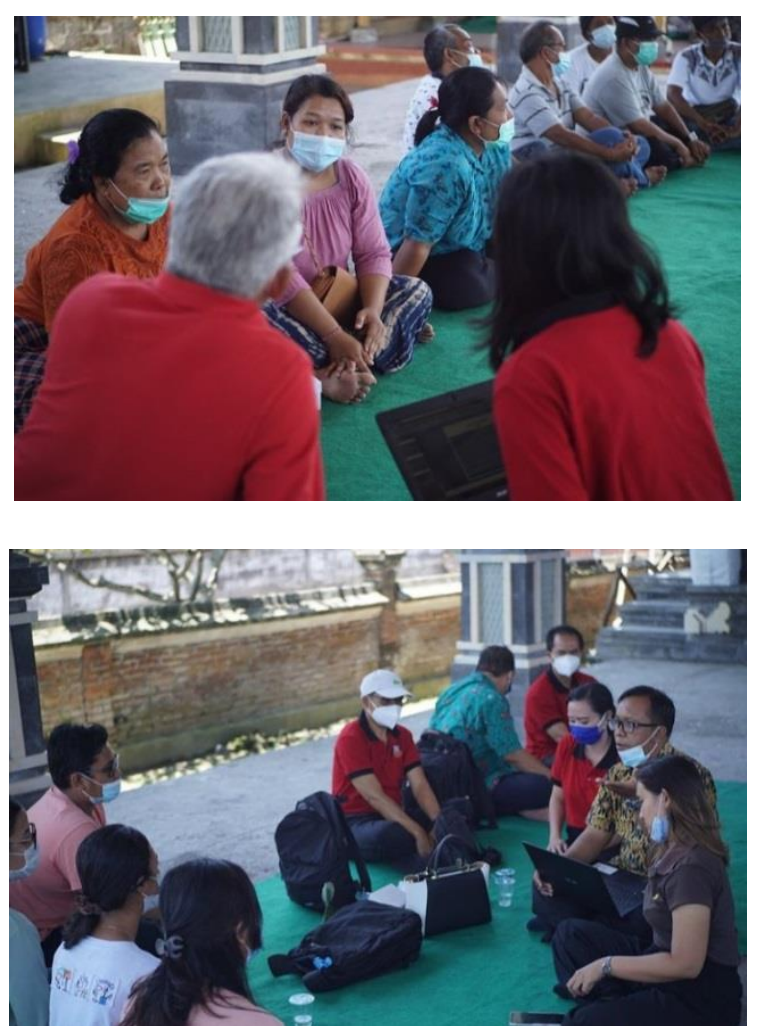

\section{Gambar 3. Pengajaran Bahasa Inggris Tour Guide}

Pelaksanaan ini diselenggarakan secara intensif guna mendapatkan hasil yang optimal bagi masyarakat dan pemerintah setempat untuk meningkatkan bahasa Inggris Tour Guide secara maksimal dalam rangka pengembangan pariwisata terintegrasi. Hal ini menjadi tujuan diselenggarakannya kegiatan PKM, memberikan kontribusi yang bermanfaat bagi masyarakat luas. 


\section{SIMPULAN DAN SARAN}

Program Pengabdian Kepada Masyarakat (PKM) yang diselenggarakan oleh Magister Ilmu Linguistik Universitas Warmadewa dengan sasaran masyarakat khususnya generasi muda di Kelurahan Semarapura Kaja ini memiliki tujuan yaitu meningkatkan pemahaman serta penggunaan bahasa Inggris Tour Guide. Hasil dari kegiatan ini menunjukkan kemajuan khususnya pengetahuan mitra mengenai pengaplikasian bahasa Inggris sebagai salah satu media untuk menarik minat wisatawan asing dalam rangka mendeskripsikan tempat-tempat wisata yang ada di Desa Semarapura Kaja. Saran yang tepat untuk menanggulangi kurangnya pemahaman terkait bahasa Inggris Tour Guide adalah dengan mengadakan kursus atau pelatihan secara intensif

\section{DAFTAR PUSTAKA}

Creswell, J. W. 2017. Research Design. Universitas of Nebraska.

Damayanti, L. S. (2019). Peranan Keterampilan Berbahasa Inggris dalam Industri Pariwisata. Journey, 2(1), 71-82.

Febriani Jayadi, M., \& Suryawan, I. B. (2020). Strategi Pengembangan Potensi Pariwisata di Pantai Blimbingsari Kabupaten Banyuwangi. Jurnal Destinasi Pariwisata, 8(1), 1-17.

Primadona, G. I. (2011). Perancangan Kawasan Terpadu Wisata Alam dan Budaya. Jurnal Aristektur Universitas Bandar Lampung, 1(2), 43-58.

Purnomo, R. A. (2016). Ekonomi Kreatif. Ziyad Visi Media.

Salambue, R., Fatayat, Mahdiyah, E., \& Andriyani, Y. (2020). Pengembangan Daya Tarik Objek Wisata Teluk Jering Kecamatan Tambang Kabupaten Kampar. Jurnal Pengabdian Masyarakat Multidisiplin, 4(1), 9-18.

Soedarso, Nurif, M., \& Windiani. (2014). Potensi dan Kendala Pengembangan Pariwisata Berbasis Kekayaan Alam dengan Pendekatan Marketing Places. Jurnal Sosial Humaniora, 7(2), 136-149.

Sumarin, Andiono, \& Yuliansyah. (2017). Pengembangan Ekonomi Kreatif Berbasis Wisata Budaya. Jurnal Ekonomi Bisnis Dan Kewirausahaan, 6(1), 1-17.

Suwena, I. K., \& Widyatmaja, I. G. N. (2010). Pengetahuan Dasar Ilmu Pariwisata. Pustaka Larasan.

Syukur, H. (2017). The Mastery of English Tourism Terms Achieved By the Third Year Students of SMKP Sandhy Putra Makassar. The Mastery of English Tourism Terms, 04(01), 63-74. 